\title{
Lung function decline in relation to mould and dampness in the home: the longitudinal European Community Respiratory Health Survey ECRHS II
}

\author{
Dan Norbäck, ${ }^{1}$ Jan-Paul Zock, ${ }^{2,3,4}$ Estel Plana, ${ }^{2,3,4}$ Joachim Heinrich, ${ }^{5}$ Cecilie Svanes, ${ }^{6}$ \\ Jordi Sunyer, ${ }^{2,3,4,7}$ Nino Künzli, ${ }^{2,8}$ Simona Villani, ${ }^{9}$ Mario Olivieri, ${ }^{10}$ Argo Soon, ${ }^{11,12}$ \\ Deborah Jarvis ${ }^{13}$
}

${ }^{1}$ Uppsala University, Department of Medical Sciences, Uppsala, Sweden ${ }^{2}$ Centre for Research in Environmental Epidemiology (CREAL), Barcelona, Spain ${ }^{3}$ Municipal Institute of Medical Research (IMIM-Hospital del Mar), Barcelona, Spain ${ }^{4}$ CIBER Epidemiologia y Salud Publica (CIBERESP), Spain ${ }^{5}$ Helmholtz Zentrum München, German Research Centre for Environmental Health, Institute of Epidemiology, Neuherberg, Germany

${ }^{6}$ University of Bergen, Department of Thoracic Medicine, Bergen, Norway ${ }^{7}$ Department of Experimental and Health Sciences, Pompeu Fabra University (UFP), Barcelona, Spain

${ }^{8}$ Tropical and Public Health Institute (Swiss TPH), Department of Epidemiology and Public Health, Basel, Switzerland

${ }^{9}$ University of Pavia, Department of Health Science, Pavia, Italy

${ }^{10}$ University Hospital of Verona, Occupational Medicine, Verona, Italy

${ }^{11}$ University of Tartu, Department of Public Health, Tartu, Estonia

${ }^{12}$ Research and Cooperation Centre, Archimedes Foundation, Tartu, Estonia

${ }^{13}$ Respiratory Epidemiology and Public Health Group, National Heart and Lung Institute, Imperial College, London, UK

\section{Correspondence to}

Dan Norback, Department of

Medical Science, Uppsala

University and Occupational and

Environmental Medicine,

University Hospital, SE-751 85

Uppsala, Sweden;

dan.norback@medsci.uu.se

Received 7 July 2010

Accepted 7 January 2011

Published Online First

16 February 2011

\begin{abstract}
Background There are few longitudinal studies that have examined the association of lung function decline with indoor mould and dampness. Lung function decline in relation to dampness and mould in the home has studied in adults over a 9 year period.
\end{abstract}

Methods Spirometry was performed twice in participants in the European Respiratory Health Survey (ECRHS I and II) who were initially examined aged 20-45 years, in 1990-1995 and 9 years later $(n=6443)$. Information on their current home was collected twice by interview. Dampness (water damage or damp spots) and indoor mould, ever and in the last 12 months, were assessed. A dampness score and a mould score were calculated. In addition, 3118 homes at 22 centres were inspected directly at follow-up for the presence of dampness and mould.

Results Dampness and mould were common. Overall, $50.1 \%$ reported any dampness and $41.3 \%$ any indoor mould in either ECRHS I or ECRHS II. Women with dampness at home had an additional decline in forced expiratory volume in $1 \mathrm{~s}\left(\mathrm{FEV}_{1}\right)$ of $-2.25 \mathrm{ml} / \mathrm{year}(95 \% \mathrm{Cl}$ -4.25 to -0.25$)$, with a significant trend in increased lung function decline in relation to the dampness score $(p=0.03)$. The association in women was significant when excluding those with asthma at baseline. Observed damp spots in the bedroom was associated with a significant additional decline in $\mathrm{FEV}_{1}$ of $-7.43 \mathrm{ml} /$ year $(95 \% \mathrm{Cl}-13.11$ to 1.74$)$ in women.

Conclusion Dampness and indoor mould growth is common in dwellings, and the presence of damp is a risk factor for lung function decline, especially in women.

A recent document from the $\mathrm{WHO}$ and a recent review article have concluded that there is consistent evidence for an association between damp housing conditions and respiratory symptoms among adults. ${ }^{1} 2$ These conclusions are mainly based on prevalence studies, and the main focus has been on symptoms of asthma. There is little information on lung function in relation to dampness in buildings and indoor mould exposure. Two prevalence studies found a lower forced expiratory volume in $1 \mathrm{~s}\left(\mathrm{FEV}_{1}\right)$ in subjects living in dwellings with dampness in the floor construction, ${ }^{3}$ and in staff at a rehabilitation centre with dampness and 2-ethyl-1-hexanol in the floor construction. ${ }^{4}$ Another Swedish study found associations between airway obstruction and higher concentrations of $1,3-\beta$-D-glucan in the air, a marker of fungal exposure. ${ }^{5}$ A study of subjects with asthma found that those with asthma living in damp homes had a lower $\mathrm{FEV}_{1}$ than those living in dry homes. ${ }^{6}$ In contrast, one study within the Swedish part of the European Community Respiratory Health Survey (ECRHS) did not find any association between $\mathrm{FEV}_{1}$ and dampness or mould in the home. ${ }^{7}$ One Danish study reported no association between lung function in teachers and water damage or mould exposure at school. ${ }^{8}$ The biological mechanisms as well as the causative factors related to respiratory effects of dampness and mould remain unclear. The aim of the present paper is to study lung function decline in relation to self-reported as well as observed building dampness and mould in dwellings, within the ECRHS cohort. Moreover, lung function decline in relation to some other building characteristics was studied.

\section{MATERIAL AND METHODS \\ Study population}

The ECRHS is an international study on respiratory health, covering 48 centres in 23 countries, a cohort started in 1990-1994. ${ }^{9} 10$ The ECRHS II is a follow-up study of participants in the ECRHS I; which included a random selection of adults aged 20-44 from the general population with a medical examination. ${ }^{11}$ The full protocol can be found at http://www.ecrhs.org/. In ECRHS I, 29 centres collected information on lung function and home environment. Follow-up took place from 1998 to 2002 among 7513 males and 8203 females (average response rate $=60 \%$ ). Of these, 5123 and 5810, respectively, completed the main medical questionnaire in ECRHS II. This analysis includes the random samples in 26 centres, with 25 centres located in Europe (Belgium, Estonia, France, Germany, Iceland, Italy, Norway, Spain, Sweden, Switzerland and the UK), and one outside Europe (Portland in the USA).

\section{Assessment of self-reported exposure to dampness and mould}

Information on housing characteristics was obtained from a face-to face interviewer-administered questionnaire, at the beginning and end of follow-up. It included building age, type of building, type of heating system, presence of double glazing, and type of floor covering in the bedroom and the living room. The living room was defined as the room used most at home during the day. There 
were questions on any history of "water damage in the house (broken pipes, leaks, flooding)', as well as water damage in the last 12 months. Information was collected on any history of 'mould or mildew on any surface inside the home', the location of the mould growth, and the presence of the indoor mould or mildew during the last 12 months. All these questions were asked in the same way at baseline and at follow-up. Exposure was defined as a positive response at either ECRHS I or ECRHS II, Finally, ECRHS II contained an additional question on the presence of 'wet or damp spots' on indoor surfaces other than the basement (eg, on walls, wallpaper, ceilings or carpets) in the last 12 months. Selection bias was studied by comparing reports on dampness and moulds in ECRHS I in responders and non-responders to follow-up.

In order to evaluate any dose-response relationship, a dampness score $(0-5)$ was constructed by adding the number of yes answers to the five questions on water damage or damp spots, at either ECRHS I or ECRHS II (water damage ever ECRHS I or II, water damage 12 months ECRHS I or II, damp spots ECRHS II). A similar mould score (0-4) was constructed, by adding the number of yes answers to the four questions on indoor mould in any place in the home (indoor mould ever ECRHS I or II, indoor mould 12 months ECRHS I or II).

\section{Assessment of observed building dampness}

In total, 22 centres participated in an additional indoor environmental study ('The Indoor Protocol'), which included a home visit, building inspection and collection of dust samples in $\sim 200$ homes in each centre. ${ }^{12} 13$ Four centres (Bergen, Bordeaux, Montpellier and Portland) did not participate in the indoor protocol. Information on observed building dampness and indoor mould was available from 3118 homes from the random sample. The indoor protocol contained eight questions on dampness, mould and window condensation, grouped into three variables:

Observed dampness. Are there any damp patches on the walls or ceilings of the living room, bedroom and bathroom? (three separate questions)

Observed mould. Is there any mould or mildew on the walls and ceilings in the living room, bedroom and bathroom? (three separate questions)

Window condensation. Do you get condensation on your living room/bedroom window especially in the morning in the winter? (two separate questions to the participant during the visit).

\section{Assessment of symptoms and personal characteristics}

Information on age, sex, asthma medication and smoking habits was collected from the interview-led questionnaire. Current smoking was defined as reporting actual smoking at the time of interview or within the last 12 months. Those providing inconsistent information on smoking at the two surveys $(n=88)$ were included and a dummy variable was included in the statistical models. Chronic bronchitis was defined as a combination of chronic cough and chronic phlegm. Socio-economic status (SES) was assessed, based on the subject's occupation and education level, as in a previous ECRHS study on SES and asthma and bronchitis. ${ }^{14}$ Occupational class was derived from the longest held job during the follow-up period between ECRHS I and II. Categories were based on the major group classification, using the first digit of the International Standard Classification of Occupations (ISCO). If a subject held multiple jobs during the follow-up period the lower ISCO category (ie, higher skill level) was used. The categories were: I for managers and professionals (non-manual) of major groups 1 and 2; II for technicians and associated professionals of major group 3; III for other non-manual workers of major groups 4 and 5; IV for skilled manual workers of major groups 6 and 7 ; V for semiskilled or unskilled manual workers of major groups 8 and 9; and VI for unclassifiable or unknown. Occupational class group VI comprised any individual not occupationally active during follow-up or who could not be assigned an ISCO code. SES data were only used to study association between SES and selected dampness exposures significantly related to lung function decline.

\section{Assessment of lung function and atopy}

The maximum $\mathrm{FEV}_{1}$ of up to five technically acceptable tests, which also fulfilled the American Thoracic Society criterion for reproducibility, was used as the outcome. The predicted value for each subject was calculated. ${ }^{15}$ Decline in $\mathrm{FEV}_{1}$ was expressed per year of follow-up (ECRHS II value minus ECRHS I value; a negative value represents a decline).

Twenty-two centres used the same spirometer in both ECRHS I and ECRHS II, with most having updated software on the second occasion. Eighteen used the Spiro Medics computerised dry-rolling seal spirometer system 2130 (Sensor Medics, Anaheim, California, USA). The other four centres used other comparable spirometers on both occasions. The use of different equipment did not lead to any heterogeneity in lung function change compared with other centres. Specific serum immunoglobulin E ( $\operatorname{IgE}$ ) levels against cat, timothy grass, the mould Cladosporium herbarium and the house dust mite Dermatophagoides pteronyssinus were determined by using the Pharmacia CAP System (Pharmacia Diagnostics, Uppsala, Sweden), in both ECRHS I and II. Atopy at baseline (ECRHS I) was defined as having at least one specific IgE level $>0.35 \mathrm{kU} / 1$.

\section{Statistical methods}

The statistical analysis was performed using Stata 8.0 (Stata Corporation). Lung function decline was analysed in men and women, separately, controlling for age, height, body mass index (BMI), length of follow-up and smoking category. Associations between dampness and indoor mould during follow-up (ever exposed) and lung function change were evaluated using multiple linear regression models, adjusting for centre as random intercept, age, height, BMI and smoking habits. Lung function decline $\left(\mathrm{FEV}_{1}\right)$ in those ever being exposed was compared with

Table 1 Respiratory health characteristics of the study population stratified by survey $(\mathrm{n}=6443)$

\begin{tabular}{lcc}
\hline & $\begin{array}{l}\text { ECRHS I } \\
\mathbf{n}(\%)\end{array}$ & $\begin{array}{l}\text { ECRHS II } \\
\mathbf{n}(\%)\end{array}$ \\
\hline $\begin{array}{l}\text { Smoking status } \\
\text { Never }\end{array}$ & $2844(44.1)$ & $2681(41.6)$ \\
Ex & $1392(21.6)$ & $1828(28.4)$ \\
$\quad$ Current & $2203(34.2)$ & $1876(29.1)$ \\
Ever asthma & $479(7.4)$ & $713(11.1)$ \\
Asthma medication & $153(2.4)$ & $243(3.8)$ \\
Chronic bronchitis & $185(3.1)$ & $178(3.0)$ \\
Atopy* & $1686(29.1)$ & $1680(28.3)$ \\
\hline & Mean (SD) & Mean (SD) \\
\hline FEV ${ }_{1}(1 / \mathrm{s})$ & $3.8(0.8)$ & $3.5(0.8)$ \\
Age (years) & $34.2(7.1)$ & $43.0(7.1)$ \\
BMI (kg/m $\left.{ }^{2}\right)$ & $23.9(3.8)$ & $25.5(4.4)$ \\
\hline
\end{tabular}

${ }^{*}$ At least one specific lgE level (cat, timothy grass, Cladosporium herbarium Dermatophagoides pteronyssinus) $>0.35 \mathrm{kU} / \mathrm{l}$.

BMI, body mass index; ECHRS, European Community Respiratory Health Survey; $\mathrm{FEV}_{1}$, forced expiratory volume in $1 \mathrm{~s}$; $\lg \mathrm{E}$, immunoglobulin $\mathrm{E}$. 
Table 2 Dampness characteristics of the current dwellings of subjects in the cohort in ECRHS I and ECRHS II

\begin{tabular}{|c|c|c|c|}
\hline & $\begin{array}{l}\text { ECRHS I } \\
\text { Prevalence (\%) }\end{array}$ & $\begin{array}{l}\text { ECRHS II } \\
\text { Prevalence (\%) }\end{array}$ & $\begin{array}{l}\text { McNemar } \\
\text { p value }\end{array}$ \\
\hline \multicolumn{4}{|l|}{ Self-reported } \\
\hline \multicolumn{4}{|l|}{ Water damage } \\
\hline Ever & 26.8 & 28.2 & 0.061 \\
\hline 12 months & 10.9 & 10.2 & 0.167 \\
\hline \multicolumn{4}{|l|}{ Damp spots } \\
\hline 12 months & NA & 20.2 & \\
\hline \multicolumn{4}{|l|}{ Mould } \\
\hline Ever, any place & 28.9 & 24.7 & $<0.001$ \\
\hline Bathroom & 12.0 & 11.0 & 0.040 \\
\hline Bedroom & 11.2 & 10.0 & 0.017 \\
\hline Living room & 6.1 & 5.1 & 0.010 \\
\hline Kitchen & 5.7 & 3.7 & $<0.001$ \\
\hline 12 months, any place & 18.0 & 16.5 & 0.013 \\
\hline \multicolumn{4}{|l|}{ Observed $^{*}(n=3118)$} \\
\hline Damp spots (any 3 places) & NA & 18.5 & \\
\hline Mould (any 3 places) & NA & 13.5 & \\
\hline $\begin{array}{l}\text { Reported window condensation } \\
\text { in winter (any } 2 \text { places) }\end{array}$ & NA & 33.9 & \\
\hline
\end{tabular}

*Only available in ECRHS II.

ECRHS, European Community Respiratory Health Survey; NA, not available.

those always non-exposed. Associations between SES and selected dampness variables were analysed by $\chi^{2}$ test.

\section{RESULTS}

Background data related to respiratory health in ECRHS I and ECRHS II are given in table 1. The average follow-up time was 8.9 years (range: 5.8-11.7 years). During this time, active smoking decreased, particularly in men, as did the prevalence of chronic phlegm. Symptoms of asthma and airway obstruction, and BMI increased in both sexes. As expected, $\mathrm{FEV}_{1}$ declined with increasing age.

Central heating was the most prevalent heating system in the dwellings (65.0\% in ECRHS I and 66.9\% in ECRHS II); air conditioning was rare, but increased from $4.2 \%$ to $7.5 \%$. Fitted carpets and rugs were common. There was a decrease in the reported presence of fitted carpets during the follow-up, from $33 \%$ to $21 \%$ for living rooms and from $40 \%$ to $29 \%$ for bedrooms, while the use of rugs remained constant. Most had double-glazed windows, $60 \%$ at ECRHS I and $76 \%$ at ECRHS II.

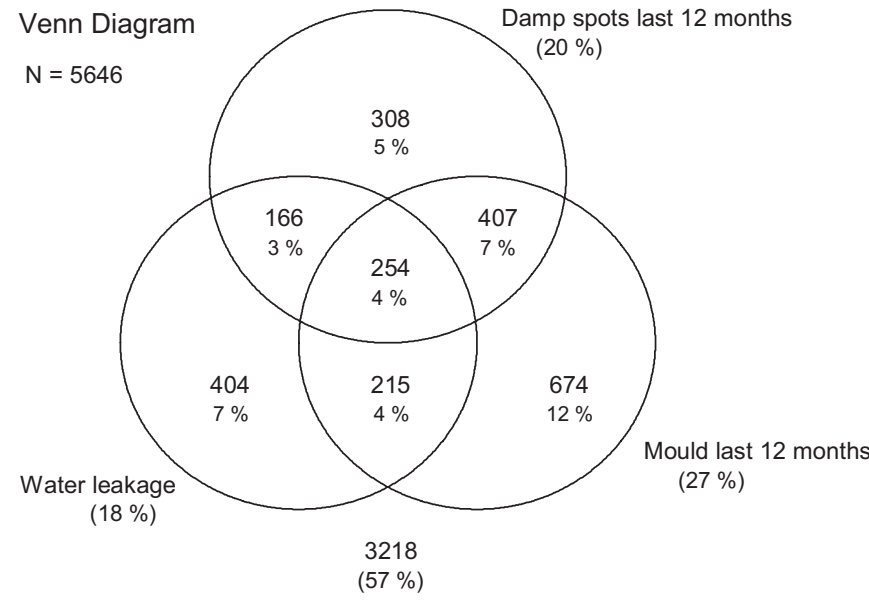

Figure 1 Venn diagram on overlap between reported damp spots, water leakage and visible mould.

Reports on indoor dampness and mould were common in both surveys (table 2). Mould was most common in the bathroom and the bedroom. There was a slight decrease in dampness and mould during the follow-up, significant in subjects who had moved to another dwelling $(49.7 \%)$, but not in those remaining in the same dwelling (50.3\%). In order to study selection effects, the prevalence of dampness and mould reported at ECRHS I was compared between participants $(n=6443)$ and non-participants $(n=7809)$ in the longitudinal study lung function study. The prevalence of mould (ever) was $28.9 \%$ in participants and $29.6 \%$ in non-participants $(p=0.34)$.The 12 months prevalence of mould was $18.0 \%$ in participants and $18.8 \%$ in non-participants $(p=0.23)$, and the prevalence of dampness (ever) was $26.8 \%$ in participants and $27.9 \%$ in non-participants $(p=0.16)$. Overall, $50.1 \%$ had ever lived in a building with water damage (damp score $>0$ ), and $41.3 \%$ had ever lived in a building with indoor mould (mould score $>0$ ). The dampness score and the mould score had poor agreement (Spearmans rho 0.33), and were independent scales $(p<0.001)$ with some overlap. Overall, $27.2 \%$ had both a mould score $>0$ and a damp score $>0$. The prevalence of observed indoor dampness and mould growth in ECRHS II was lower than the self-reported 12 months prevalence, but window condensation in either the bedroom or living room was common (table 2).

Table 3 Average additional decline in $\mathrm{FEV}_{1}$ (ml per year) in relation to dampness and mould $(\mathrm{n}=6443)$

\begin{tabular}{|c|c|c|c|c|}
\hline & \multicolumn{2}{|c|}{ Men $(n=3195)$} & \multicolumn{2}{|c|}{ Women $(n=3248)$} \\
\hline & $\begin{array}{l}\text { Baseline } \\
\text { decline }\end{array}$ & $\begin{array}{l}\text { Adjusted difference } \\
\text { in decline }(95 \% \mathrm{Cl}) \dagger\end{array}$ & $\begin{array}{l}\text { Baseline } \\
\text { decline }\end{array}$ & $\begin{array}{l}\text { Adjusted difference } \\
\text { in decline }(95 \% \mathrm{Cl}) \dagger\end{array}$ \\
\hline \multicolumn{5}{|l|}{ Self-reported } \\
\hline Water damage (12 months) & -27.30 & $0.59(-2.68$ to 3.86$)$ & -23.05 & $-2.13(-4.59$ to 0.32$)$ \\
\hline Mould (12 months) & -27.07 & $0.02(-2.73$ to 2.78$)$ & -23.30 & $0.07(-2.02$ to 2.15$)$ \\
\hline Damp spots* (12 months) & -27.19 & $1.07(-2.00$ to 4.13$)$ & -22.74 & $-1.21(-3.53$ to 1.10$)$ \\
\hline Dampness (score $>0$ vs score $=0$ ) & -27.87 & $1.43(-1.12$ to 3.98$)$ & -22.11 & $-2.25(-4.25$ to -0.25 \\
\hline Mould (score $>0$ vs score $=0$ ) & -27.07 & $0.00(-2.50$ to 2.50$)$ & -22.85 & $-0.83(-2.76$ to 1.09$)$ \\
\hline Observed $^{*}$ & $(n=1447)$ & & $(n=1671)$ & \\
\hline Damp spots (any 3 places) & -24.85 & $-2.16(-7.32$ to 3.00$)$ & -21.80 & $-3.14(-6.95$ to 0.68$)$ \\
\hline Mould (any 3 places) & -25.60 & $3.06(-2.82$ to 8.94$)$ & -22.28 & $-1.04(-5.48$ to 3.40$)$ \\
\hline Window condensation in winter & -24.35 & $0.06(-4.26$ to 4.37$)$ & -22.34 & $0.11(-3.07$ to 3.29$)$ \\
\hline
\end{tabular}

*Only available in ECRHS II.

†Fixed adjusted for mid-age, mid-age ${ }^{2}$, height, mid-BMI, change in BMI and smoking category defined according to both ECRHS I and ECRHS II, and centre as random effect.

BMI, body mass index; ECHRS, European Community Respiratory Health Survey; FEV ${ }_{1}$, forced expiratory volume in $1 \mathrm{~s}$. 
Table 4 Decline in $\mathrm{FEV}_{1}$ (ml/year) in relation to a dampness score, stratified by sex

\begin{tabular}{|c|c|c|c|c|c|c|}
\hline & \multicolumn{3}{|c|}{ Males $(\mathrm{N}=\mathbf{2 8 6 7 )}$} & \multicolumn{3}{|c|}{ Females $(\mathrm{N}=\mathbf{2 8 8 6})$} \\
\hline & $\bar{n}$ & Coefficient $(95 \% \mathrm{CI})^{*}$ & $\overline{\text { p Value }}$ & $\bar{n}$ & Coefficient $(95 \% \mathrm{Cl})^{*}$ & p Value \\
\hline \multicolumn{7}{|c|}{ Dampness score } \\
\hline 0 & 1473 & -27.87 (ref.) & & 1398 & -22.05 (ref.) & \\
\hline 1 & 668 & $1.76(-1.36$ to 4.88$)$ & 0.268 & 666 & $-2.41(-4.88$ to 0.06$)$ & 0.056 \\
\hline 2 & 411 & $1.28(-2.52$ to 5.07$)$ & 0.509 & 455 & $-0.44(-3.30$ to 2.43$)$ & 0.766 \\
\hline 3 or more & 315 & 0.83 ( -3.41 to 5.07$)$ & 0.700 & 367 & $-4.34(-7.48$ to -1.19$)$ & 0.007 \\
\hline Trend & & $0.34(-0.77$ to 1.46$)$ & 0.545 & & $-0.90(-1.71$ to -0.08$)$ & 0.032 \\
\hline
\end{tabular}

As can be seen from figure 1 , the three questions on dampness/mould in the last 12 months had only partial overlap, and many subjects had reported only one type of dampness-related exposure.

Decline in $\mathrm{FEV}_{1}$ with exposure is shown in table 3. No association of lung function decline with reported or directly observed damp or mould was seen in men. However, there was an additional lung function decline in women with a dampness score $>0$ (mean additional annual decline by $-2.25 \mathrm{ml} ; 95 \% \mathrm{CI}$ -4.25 to $-0.25 \mathrm{ml}$ ), added to the decline of $-22.11 \mathrm{ml}$ in never exposed women (table 3).

Moreover there was also evidence of a trend for decline in lung function with increasing damp score in women $(p=0.03)$ (table 4). There was no evidence of an association of decline in lung function with mould score in men or women (data not shown). When analysing lung function decline in relation to other building factors, there were no significant associations except for a minor effect of rugs in the bedroom, with an additional lung function decline of $-1.35 \mathrm{ml}$ ( $95 \% \mathrm{CI}-2.66$ to $-0.04 \mathrm{ml}$ ) in men.

When excluding participants with asthma at baseline ('ever asthma'), an association of lung function decline with reported water damage in the last 12 months was observed in women ( $\mathrm{n}=2989$ : additional decline in $\mathrm{FEV}_{1}-2.89 \mathrm{ml}$; 95\% CI -5.36 to to $-0.41 \mathrm{ml}$ ), as well as for dampness score $>0$ (additional decline $-3.00 \mathrm{ml}$; $95 \% \mathrm{CI}-5.00$ to $-0.99 \mathrm{ml}$ ) in comparison with those with a dampness score $=0$. In women with asthma at baseline $(n=255)$ there was no evidence of an association with water damage in the last 12 months (additional decline by $9.24 \mathrm{ml}$; $95 \% \mathrm{CI}-3.07$ to $21.55 \mathrm{ml}$ ), or for dampness score $>0$ (additional decline $6.83 \mathrm{ml}$; 95\% CI -3.59 to $17.24 \mathrm{ml}$ ). No association with these dampness measures was seen in men either with or without asthma. When restricting the analysis to never-smokers, there was no significant additional lung function decline in women in relation to dampness score (additional decline per unit change in dampness score $-1.68 \mathrm{ml}$; 95\% CI -4.75 to $1.38 \mathrm{ml}$ ). When restricting the analysis to ever-smokers, there was no significant additional lung function decline in women in relation to dampness score (additional decline per unit change in dampness score $-2.41 \mathrm{ml}$; $95 \% \mathrm{CI}-5.07$ to $0.25 \mathrm{ml}$ ). No association with dampness score was seen in either smoking or non-smoking men. When analysing observed dampness at different locations, there was a significant additional decline of lung function by $-7.43 \mathrm{ml}(95 \% \mathrm{CI}-13.11$ to $-1.74 \mathrm{ml})$ in women with damp spots in the bedroom $(p=0.008)$. There was a similar but non-significant trend of an additional decline by $-4.84 \mathrm{ml}(95 \% \mathrm{CI}-12.50$ to $2.85 \mathrm{ml})$ in men exposed to damp spots in the bedroom (table 5).

Since SES could be a potential confounder, associations between SES and dampness score ( $>0$ vs 0 ), and observed dampness in the bedroom were analysed for women. There was no significant association between SES and dampness score $>0(p=0.32)$. The proportion of women with higher SES was slightly higher in homes with a dampness score $>0$ versus 0 (eg, $28 \%$ vs $24 \%$ of managers and professionals). Moreover, there was no significant association between SES and observed damp spots in the bedroom $(p=0.29)$. The proportion of women with higher SES was slightly lower in homes with observed damp spots in the bedroom (eg, $22 \%$ vs $26 \%$ of managers and professionals).

\section{DISCUSSION}

The study did not find any association between indoor mould growth in the home and increased lung function decline in young adults. We saw no association between window condensation in winter time (an indicator of insufficient ventilation in relation to dampness) and lung functional decline. Since the study is a relatively large longitudinal multicentre study, these negative results may be conclusive. However, we did find some evidence that other aspects of building dampness, measured as either water leakage or damp spots, are associated with accelerated lung function decline in women. There were no major changes in reports on dampness and mould during the follow-up, and no indication of selection effects in relation to exposure. Response bias could exist for self-reported dampness and mould, but is less likely for directly observed measures of exposure, and we found associations between both reported and observed signs of dampness. Thus, it is less likely that our conclusions are severely affected by recall bias or selection bias.

Table 5 Decline in $\mathrm{FEV}_{1}$ (ml/year) in relation to site of observed damps pots, stratified by sex

\begin{tabular}{llllll}
\hline & Males (N=1274) & & & \multicolumn{2}{l}{ Females (N=1423) } \\
\cline { 2 - 3 } & No. exposed & Coefficient $\mathbf{( 9 5 \% ~} \mathbf{~ I )})^{*}$ & & No. exposed & Coeffficient (95\% Cl)* \\
\hline Living room & -24.61 & $2.92(-6.34$ to 12.17$)$ & & -22.52 & $0.54(-5.63$ to 6.71$)$ \\
Bedroom & -24.45 & $-4.82(-12.50$ to 2.85$)$ & & -22.05 & $-7.43(-13.11$ to -1.74$)$ \\
Bathroom & -24.65 & $-2.11(-8.69$ to 4.47$)$ & & -22.02 & -3.60 (-8.47 to 1.27$)$ \\
\hline
\end{tabular}

*Fixed adjusted for mid-age, mid-age ${ }^{2}$, height, mid-BMI, change in BMI and smoking category defined according to both ECRHS I and ECRHS II, and centre as random effect.

BMI, body mass index; ECHRS, European Community Respiratory Health Survey; FEV ${ }_{1}$, forced expiratory volume in $1 \mathrm{~s}$. 
Dampness and indoor moulds were common, both at baseline and at follow-up. There was only partial overlap between water leakage, damp spots and visible indoor mould, which illustrates that these are different aspects of dampness, which may lead to different types of exposure which could have different impacts on respiratory health. Such exposures could include moulds and bacteria, microbial compounds such as endotoxin from bacteria, $1,3-\beta$-D-glucan and other fungal cell wall compounds from moulds, ${ }^{16}$ mycotoxins, ${ }^{17}$ volatile organic compounds of microbial origin (MVOC) $)^{18}$ and chemicals emitted from damp building materials (eg, 2-ethyl-1-hexanol). ${ }^{4}$ Water leakage may lead to increased humidity in the building construction, causing hidden growth of moulds and bacteria, or chemical degradation of certain building materials. ${ }^{4}$ Damp spots can be an indicator of increased dampness in the construction. In a previous crosssectional study, there was a significantly lower $\mathrm{FEV}_{1}$ in dwellings with signs of dampness in the floor, due to increased humidity in the concrete floor, while there were no association between visible indoor mould and $\mathrm{FEV}_{1}{ }^{3}{ }^{3}$

Associations between lung function decline and self-reported and directly observed dampness measures were only seen in women, and the association with observed 'damp spots' was only seen for damp spots in the bedroom. This could be because time spent in the bedroom is relatively long and bedrooms are often small and poorly ventilated, as compared with other parts of the home. The additional mean lung function decline, $-2.25 \mathrm{ml} /$ year for self-reported dampness and $-7.43 \mathrm{ml} /$ year for observed dampness in the bedroom, is of the same order of magnitude as estimated for moderate tobacco smoking in the same ECRHS cohort. Smoking 10-20 cigarettes per day led to an additional $\mathrm{FEV}_{1}$ decline of $-4 \mathrm{ml} /$ year, and those smoking $>20$ cigarettes per day had an additional decline of $-9.5 \mathrm{ml} /$ year. ${ }^{19}$ The reason for the sex difference in effect remains unclear, but could be due to either higher susceptibility or a longer exposure time in the dwelling for women. There are few studies on sex differences in relation to mould and dampness exposure, although one Canadian study does suggest that women are more susceptible than men to the effects of dampness. $^{20}$ The fact that the association was observed for water leakage and damp spots but not for visible mould growth suggests that dampness-related exposures other than fungal growth on indoor surfaces could be responsible. Two previous studies showing associations between dampness in the floor construction and airway obstruction ${ }^{3} 4$ illustrate that emissions from building dampness that are not related to visible mould growth could influence lung function.

In conclusion, water leakage, damp spots and indoor mould are common in participating centres of the ECRHS, and there is evidence that increased dampness such as water leakage and damp spots is related to additional adult lung function decline in women. This indicates a need to reduce building dampness in dwellings.

Funding The coordination of ECRHS II was supported by the European Commission, as part of their Quality of Life programme. The following bodies funded the local studies in ECRHS II included in this paper: Albacete: Fondo de Investigaciones Santarias (FIS) (grant code: 97/0035-01, 99/0034-01 and 99/0034-02). Hospital Universitario de Albacete, Consejeria de Sanidad; Antwerp: FWO (Fund for Scientific Research)-Flanders Belgium (grant code: G.0402.00), University of Antwerp, Flemish Health Ministry; Barcelona: SEPAR, Public Health Service (grant code: R01 HL62633-01), Fondo de Investigaciones Santarias (FIS) (grant code: 97/0035-01, 99/0034-01 and 99/0034-02) CIRIT (grant code: 1999SGR 00241) 'Instituto de Salud Carlos III' Red de Centros RCESP, C03/09 and Red RESPIRA, C03/011; Basel: Swiss National Science Foundation, Swiss Federal Office for Education \& Science, Swiss National Accident Insurance Fund (SUVA); Bergen: Norwegian Research Council, Norwegian Asthma \& Allergy Association (NAAF), Glaxo Wellcome AS, Norway Research Fund; Bordeaux: Institut Pneumologique d'Aquitaine; Erfurt: GSF-National
Research Centre for Environment \& Health, Deutsche Forschungsgemeinschaft (DFG) (grant code FR 1526/1-1); Galdakao: Basque Health Department; Goteborg: Swedish Heart Lung Foundation, Swedish Foundation for Health Care Sciences \& Allergy Research, Swedish Asthma \& Allergy Foundation, Swedish Cancer \& Allergy Foundation; Grenoble: Programme Hospitalier de Recherche Clinique-DRC de Grenoble 2000 no. 2610, Ministry of Health, Direction de la Recherche Clinique, Ministere de l'Emploi et de la Solidarite, Direction Generale de la Sante, CHU de Grenoble, Comite des Maladies Respiratoires de I'Isere; Hamburg: GSF-National Reasearch Centre for Environment \& Health, Deutsche Forschungsgemeinschaft (DFG) (grant code MA 711/4-1); Ipswich and Norwich: Asthma UK (formerly known as National Asthma Campaign) (UK); Huelva: Fondo de Investigaciones Santarias (FIS) (grant code: 97/0035-01, 99/0034-01 and 99/0034-02); Montpellier: Programme Hospitalier de Recherche Clinique-DRC de Grenoble 2000 no. 2610, Ministry of Health, Direction de la Recherche Clinique, CHU de Grenoble, Ministere de l'Emploi et de la Solidarite, Direction Generale de la Sante, Aventis (France), Direction Régionale des Affaires Sanitaires et Sociales Languedoc-Roussillon; Oviedo: Fondo de Investigaciones Santarias (FIS) (grant code: 97/0035-01, 99/0034-01 and 99/0034-02); Paris: Ministere de l'Emploi et de la Solidarite, Direction Generale de la Sante, UCB-Pharma (France), Aventis (France), Glaxo France, Programme Hospitalier de Recherche Clinique-DRC de Grenoble 2000 no. 2610, Ministry of Health, Direction de la Recherche Clinique, CHU de Grenoble; Pavia: Glaxo-SmithKline Italy, Italian Ministry of University and Scientific and Technological Research (MURST), Local University Funding for research 1998 and 1999 (Pavia, Italy); Portland: American Lung Association of Oregon, Northwest Health Foundation, Collins Foundation, Merck Pharmaceutical; Reykjavik: Icelandic Research Council, Icelandic University Hospital Fund; Tartu: Estonian Science Foundation; Turin: ASL 4 Regione Piemonte (Italy), AO CTO/ICORMA Regione Piemonte (Italy), Ministero dell'Università e della Ricerca Scientifica (Italy), Glaxo Wellcome spa (Verona, Italy); Umeå: Swedish Heart Lung Foundation, Swedish Foundation for Health Care Sciences \& Allergy Research, Swedish Asthma \& Allergy Foundation, Swedish Cancer \& Allergy Foundation; Uppsala: Swedish Heart Lung Foundation, Swedish Foundation for Health Care Sciences \& Allergy Research, Swedish Asthma \& Allergy Foundation, Swedish Cancer \& Allergy Foundation.

\section{Competing interests None.}

\section{Patient consent Obtained.}

Ethics approval This study was conducted with the approval of the appropriate body at each participating centre.

Provenance and peer review Not commissioned; externally peer reviewed.

\section{REFERENCES}

1. World Health Organization (WHO) Regional office for Europe. Guidelines for Indoor Air Quality: Dampness and Mould. Copenhagen, Denmark: WHO Regional Office for Europe, 2009:1-228.

2. Fisk WJ, Lei-Gomez 0, Mendell MJ. Meta-analysis of the associations of respiratory health effects with dampness and moulds in homes. Indoor Air 2007:17:284-96.

3. Norbäck D, Björnsson E, Janson C, et al. Current asthma and biochemical signs of inflammation in relation to building dampness in dwellings. Int J Tuberc Lung Dis 1999:3:368-76.

4. Wieslander G, Kumlin A, Norbäck D. Dampness and 2-ethyl-1-hexanol in floor construction of rehabilitation center: health effects in staff. Arch Environ Occup Health 2010;65:3-11.

5. Thorn J, Rylander R. Airways inflammation and glucan in a rowhouse area. $A m \mathrm{~J}$ Respir Crit Care Med 1998;157:798-803.

6. Williamson IJ, Martin CJ, McGill G, et al. Damp housing and asthma: a case-control study. Thorax 1997;52:229-34.

7. Gunbjörnsdottir MI, Norbäck D, Plaschke P, et al. The relationship between indicators of building dampness and respiratory health in young Swedish adults. Respir Med 2003;97:302-7.

8. Ebbehoj NE, Meyer HW, Wurtz $\mathrm{H}$, et al. Moulds in floor dust, building-related symptoms, and lung function in male and female schoolteachers. Indoor Air 2005;15(Suppl 10):7-16.

9. Burney PGJ, Luczynska CM, Chinn S, et al. The European Community Respiratory health survey. Eur Respir J 1994;7:954-60.

10. Janson C, Anto J, Burney P, et al. The European Community Respiratory Health Survey: what are the main results so far? Eur Respir J 2001;18:598-611.

11. Chinn S, Jarvis D, Burney $P$, et al. Increase in diagnosed asthma but not in symptoms in the European Community Respiratory Health Survey. Thorax 2004:59:646-51.

12. Heinrich J, Bedada GB, Zock JP, et al. Cat allergen level: its determinants and relationship to specific IgE to cat across European centers. J Allergy Clin Immunol 2006;118:674-81.

13. Zock JP, Heinrich J, Jarvis D, et al. Distribution and determinants of house dust mite allergens in Europe: the European Community Respiratory Health Survey II. J Allergy Clin Immunol 2006;118:682-90.

14. Ellison-Loschmann L, Sunyer J, Plana E, et al. European Community Respiratory Health Survey. Socioeconomic status, asthma and chronic bronchitis in a large community-based study. Eur Respir J 2007;29:897-905. 
15. European Community for Coal and Steel. Standardization of lung function tests. Clin Resp Physiol 1983;19(Suppl 5):22-7.

16. Douwes J. $(1 \rightarrow 3)$-Beta-o-glucans and respiratory health: a review of the scientific evidence. Indoor Air 2005;15:160-9.

17. Robbins CA, Swensson LJ, Nealley ML, et al. Health effects of mycotoxins in indoor air: a critical review. Appl Occup Environ Hyg 2000:15:773-84.
18. Fisher G, Dott W. Relevance of airborne fungi and their secondary metabolites for environmental, occupational and indoor hygiene. Arch Microbiol 2003;179:75-82.

19. Svanes C, Sunyer J, Plana E, et al. Early life origins of chronic obstructive pulmonary disease. Thorax 2010:65:14-20.

20. Rennie D, Chen Y, Lawson J, et al. Different effect of damp housing on respiratory health in women. J Am Med Womens Assoc 2005:60:46-51.

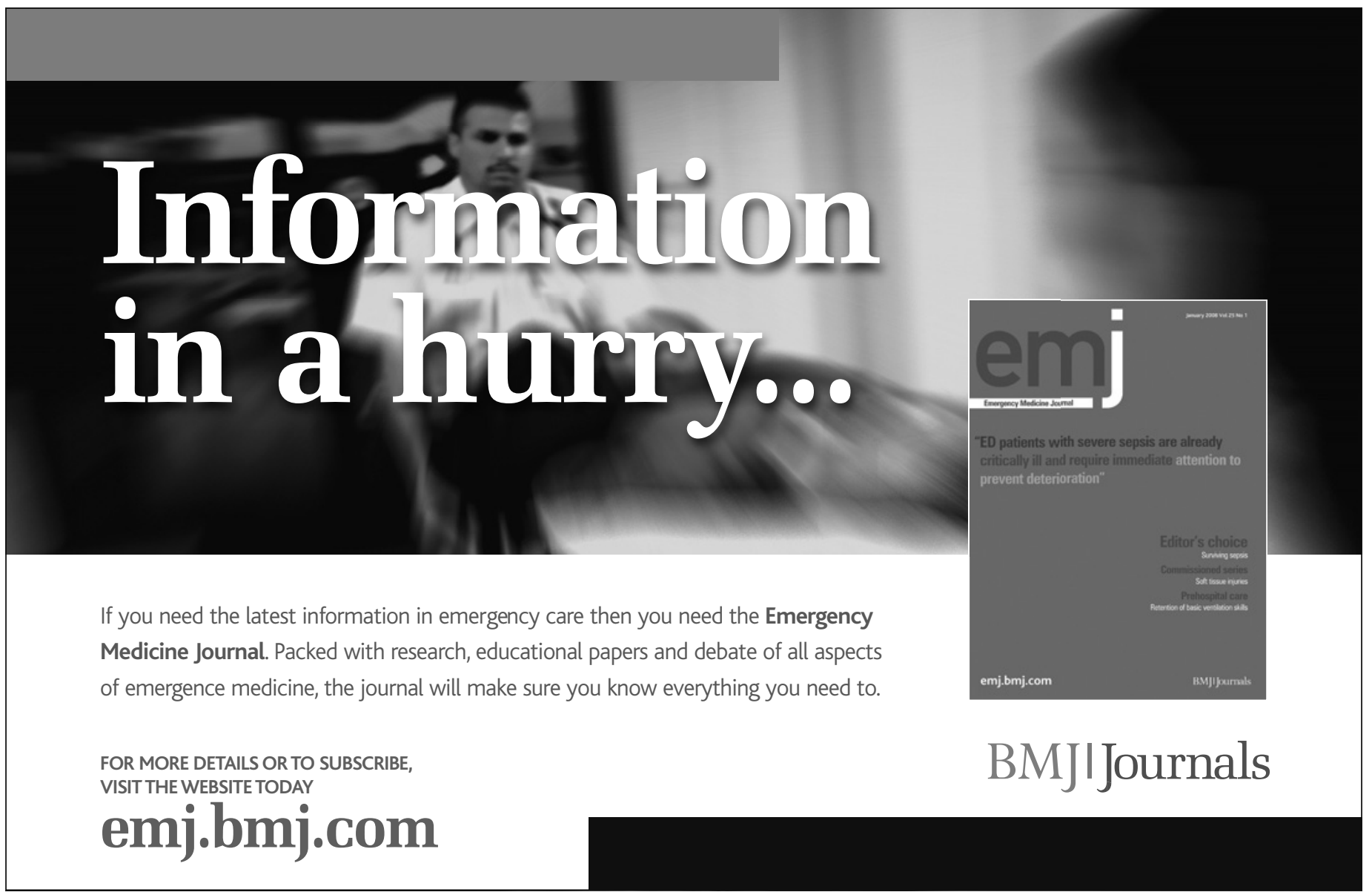

